УДК 342.951

DOI https://doi.org/10.32837/pyuv.v0i2(27).198

\author{
Ю. В. Кузьменко \\ доктор педагогічних наук, доцент, \\ професор кафедри адміністративного права та адміністративного процесу \\ Херсонського факультету \\ Одеського державного університету внутрішніх справ
}

\title{
АДМІНІСТРАТИВНА ДІЯЛЬНІСТЬ НАЦІОНАЛЬНОЇ ПОЛІЦЇ: ПРОТИДІЯ ТА ЗАПОБІГАННЯ ДОМАШНЬОМУ НАСИЛЬСТВУ
}

Проблеми домашнього насильства сьогодні гостро постали не лише в Україні, а й у світі. Наприклад, в Німеччині у 2017 році кожних два-три дні фіксувалися випадки загибелі щонайменше однієі жінки від рук партнера або експартнера [2]; у Великій Британії у 2018 році зареєстровано 650 тисяч випадків домашнього насильства та знущань [1]; в Україні кожного року від рук партнерів гинуть 600 жінок [10].

Як бачимо, проблема пошуку шляхів протидії та запобігання насильству в сім'ї є сьогодні актуальною. Державна політика щодо боротьби із такими правопорушеннями ведеться цілеспрямовано та систематично. Постійно розширюється та удосконалюється законодавчий простір, де імплементується конструктивний вітчизняний досвід з новітньою ефективною європейською практикою.

У наукових розвідках вітчизняних вчених широке коло досліджень присвячене проблемам домашнього насильства. Зокрема, О. Стрельченко, Л. Шевченко присвятили свої дослідження порівняльно-правовому аспекту понять «домашне насильство» i «насильство в сім'ї». В. Пивоваров, А. Ілліна здійснили криміналістичний аналіз законодавства про запобігання і протидію домашньому насильству. О. Простибоженко окреслював аспекти винесення заборонного та обмежувального приписів. М. Євсюкова, Г. Христова, О. Шаповалова висвітлювали судову практику, пов'язану з вчиненням насильства в сім'ї в Україні.

Мета статті - висвітлити адміністративний аспект діяльності Національної поліції щодо реалізації Закону України «Про запобігання та протидію домашньому насильству», розкрити шляхи вирішення зазначеної проблеми працівниками поліції.

Закон України «Про запобігання та протидію домашньому насильству» в правовому полі України достатньо новий (2017р.). Цілком логічно, що його реалізація органами Національної поліції відбувається поступово.

Законодавчою нормою розширене коло осіб, відносно яких може вчинятися домашне насилля (у статті 3 визначений цей перелік). Важливим $\epsilon$ й уточнення щодо факту проживання потерпілого та кривдника (як спільного, так і окремого). Зміни у переліку були необхідні і затребувані ча- сом. Було враховано прогалини відповідного попереднього закону про насильство в сім’ї. Такий підхід дозволяє притягнути до кримінальної та адміністративної відповідальності ширше коло винних, що вчиняють психологічне, економічне, сексуальне чи фізичне насильство [4].

Одними із органів та установ, на які покладаються функції із здійснення заходів у сфері запобігання та протидії домашньому насильству, $\epsilon$ підрозділи органів Національної поліції України.

Повноваження уповноважених підрозділів органів Національної поліції України у сфері запобігання та протидії домашньому насильству представлені у статті 10. Зазначимо, що основне навантаження в Національній поліції щодо протидії домашньому насильству покладене на дільничних офіцерів поліції, проте й інші підрозділи (патрульна, кримінальна, спеціальна поліція та поліція охорони і особливого призначення) мають реагувати на ці правопорушення у разі звернення про допомогу будь-якого громадянина. Варто підкреслити, що якщо працівник поліції перебуває у відпустці, то у разі звернення до нього громадян з причини правопорушення він зобов'язаний повідомити про ситуацію у свій відділ або зателефонувати у чергову частину і не полишати із проблемою потерпілого сам на сам.

Першою, хто виїжджає на виклики з домашнього насилля, є патрульна поліція. Поліція отримує повідомлення на 102, приймає повідомлення з національної гарячої лінії з попередження домашнього насильства, торгівлі людьми та гендерної дискримінації чи з інших джерел та організовує виїзд патрульної бригади на місце правопорушення. У деяких регіонах України першою за цим напрямом на місце події виїжджає створена спеціально група реагування поліції «Поліна». В межах повноважень поліції знаходиться прийом і розгляд заяв про вчинення домашнього насильства.

Відповідно до Закону України «Про Національну поліцію» поліцейський може застосувати такий поліцейський захід, як проникнення до житла чи іншого володіння особи. Поліцейський має право «проникнути до житла чи іншого володіння особи без вмотивованого рішення суду лише в невідкладних випадках, пов'язаних із <...> припиненням злочину, що загрожує життю осіб, які 
перебувають у житлі або іншому володінні» [9], про що обов' язково складається протокол.

Спеціальні заходи, які входять до компетенції поліції щодо протидії домашньому насильству, окреслені в таких статтях закону України «Про запобігання та протидію домашньому насильству»: ст. 24 «Спеціальні заходи щодо протидії домашньому насильству»; ст. 25 «Терміновий заборонний припис стосовно кривдника. Взяття на профілактичний облік кривдників та проведення 3 ними профілактичної роботи»; ст. 28 «Виконання програм для кривдників».

Така практика для України є новою. Терміновий заборонний припис виписують працівники поліції строком на 10 днів, оцінивши ризики загрози життю постраждалої особи. У спеціально розробленій формі поліцейський дає оцінку ризиків, ця процедура здійснюється відповідно до Наказу Міністерства соціальної політики України, Міністерства внутрішніх справ України від 13 березня 2019 року № 369/180 «Порядок проведення оцінки ризиків вчинення домашнього насильства». Документ визначає процедуру проведення оцінки вірогідності продовження чи повторного вчинення домашнього насильства, настання тяжких або особливо тяжких наслідків його вчинення, а також смерті постраждалої особи з метою визначення ефективних заходів реагування, спрямованих на припинення такого насильства та попередження його повторного вчинення [6].

Терміновий заборонний припис включає такі заходи: містить вимогу до кривдника покинути місце проживання чи перебування потерпілого; забороняє вхід чи перебування в місці проживання чи перебування потерпілого; забороняє здійснювати контакт у будь-якій формі з постраждалим. Ці заходи можуть бути застосовані відносно кривдника як поодинці, так і в комплексі (два чи три). Незалежно від майнових прав на житло поліцейські мають право на виселення кривдника відповідно до припису, якщо від досяг вісімнадцятиріччя. Безпосередньо процедура винесення такого припису закріплена Наказом Міністерства внутрішніх справ України «Порядок винесення уповноваженими підрозділами органів Національної поліції України термінового заборонного припису стосовно кривдника» (2018 р.). Важливою новелою $є$ й те, що припис виноситься за заявою постраждалої особи, а також за власною ініціативою працівника уповноваженого підрозділу поліції згідно з результатами оцінки ризиків [8]. Також ведеться журнал реєстрації повідомлень про місце тимчасового перебування кривдника, якому винесено терміновий заборонний припис стосовно кривдника, і журнал видачі бланків термінових заборонних приписів стосовно кривдника. Бланк заборонного термінового припису має спеціальну встановлену форму та номер.
Серія такого бланка складається із двох літер, номер - із шестизначного цифрового показника, що виконуються способом високого друку фарбою чорного кольору, яка під дією ультрафіолетового опромінення набуває свічення зеленого кольору. Серія і номер є однаковими для припису, першої та другої його копій [8]. Якщо бланк зіпсовано, він вважається недійсним і підлягає знищенню в установленому порядку.

Також важливими аспектами адміністративної діяльності дільничних офіцерів поліції у контексті нашого дослідження є взяття на профілактичний облік кривдника та проведення з кривдником профілактичної роботи.

Що стосується відповідальності поліцейських, то вона прописана у ст. 31: «Посадові та службові особи, визнані винними у порушенні вимог законодавства у сфері запобігання та протидії домашньому насильству, несуть відповідальність відповідно до закону» [7].

Варто зазначити, що Кодекс України про адміністративні правопорушення із появою Закону України «Про запобігання та протидію домашньому насильству» було доповнено такими статтями:

- ст. $39^{1}$, яка зазначає, що за вчинення домашнього насильства суд може винести рішення про направлення на проходження програми для особи, яка вчинила домашнє насильство;

- ст. $173^{2}$, яка розкриває процедуру настання адміністративної відповідальності у разі вчинення домашнього насильства або невиконання термінового заборонного припису. Ця процедура - це накладення штрафу від десяти до двадцяти неоподатковуваних мінімумів доходів громадян або громадські роботи на строк від тридцяти до сорока годин чи адміністративний арешт на строк до семи діб;

- ст. $173^{2}$, яка визначає, що особа може бути притягнута до адміністративної відповідальності, якщо протягом року така особа знов була притягнута за домашнє насилля. Ця стаття передбачає санкцію у вигляді накладення штрафу від двадцяти до сорока неоподатковуваних мінімумів доходів громадян або громадські роботи на строк від сорока до шістдесяти годин чи адміністративний арешт на строк до п'ятнадцяти діб [3].

У разі звернення з заявою про домашне насильство працівники поліції зобов' язані виконати такі дії:

1) увести в Єдиний державний реєстр досудових розслідувань інформацію про подання заяви щодо домашнього насильства;

2) видати потерпілій стороні повідомлення про початок досудового розслідування, в якому буде зазначено номер з Єдиного реєстру;

3) у разі наявності видимих тілесних ушкоджень надати скерування на судово-медичну експертизу; 
4) якщо наявні такі ознаки злочину, як нанесення легких чи середньої тяжкості тілесних ушкоджень, мордування, побої, зґвалтування, сексуальне домагання та інше, поліцейські повинні розпочати досудове розслідування вчиненого злочину;

5) передати інформацію для Єдиного державного реєстру випадків домашнього насильства та насильства за ознакою статі.

Навіть за умови, що ознак домашнього насильства не було встановлено, поліцейські повинні виконати такі дії:

- винести офіційне попередження про неприпустимість вчинення насильства в сім'ї особі, яка вчинила насильство;

- поставити на профілактичний облік особу, яка вчинила насильство в сім'ї;

- винести захисний припис особі, яка повторно вчинила насильство в сім'ї після отримання офіційного попередження;

- відвідати сім'ю, де чиниться насильство, провести роз'яснювально-виховну роботу з насильником і проінформувати членів сім'ї про права, заходи й послуги, якими вони можуть скористатися;

- скласти протокол про вчинення насильства в сім'ї за статтею $173^{2}$ Кодексу України про адміністративні правопорушення і направити його до суду [5].

Таким чином, адміністративна діяльність Національної поліції суттєво розширена заходами, що можуть застосовуватися відносно кривдника як у разі вчинення ним домашнього насильства, так і в разі висловлення погрози його здійснення. Усі ці заходи покликані захищати постраждалих осіб від домашнього насильства та попереджувати його. Перспектива подальших наукових розвідок пов'язана із пошуком шляхів попередження насильства в сім'ї над дітьми.

\section{Jimepamypa}

1. Домашне насильство в Британії залишається великою проблемою. URL: https://www.radiosvoboda. org/a/28931468.html (дата звернення: 01.09.2019).

2. Домашне насильство: як 3 ним борються в Німеччині. URL: https://www.dw.com/uk/домашнєнасильство-як-з-ним-борються-в-німеччині а-46454500 (дата звернення: 01.09.2019).

3. Кодекс України про адміністративні правопорушення : Закон України від 07.12.1984 p. № 80731-Х. URL: https://zakon.rada.gov.ua/laws/show/80731-10 (дата звернення: 03.09.2019).

4. Кузьменко Ю.В. Протидія домашньому насиллю: новели законодавства України. Право і суспільство. 2019. № 2 Ч. 1. С. 131-136.

5. Насильство в сім'ї. Як захистити себе та родину. Правовий простір. Безоплатна правова допомога в Україні. URL: http://legalspace.org/ua/biblioteka/ item/10088-nasylstvo-v-sim-i-yak-zakhystyty-sebe-tarodynu (дата звернення: 06.10.2019).

6. Порядок проведення оцінки ризиків вчинення домашнього насильства : Наказ Міністерства соціальної політики України, Міністерства внутрішніх справ України від 13.03.2019 р. № 369/180. URL: https://zakon.rada.gov.ua/laws/show/z0333-19 (дата звернення: 01.10.2019).

7. Про запобігання та протидію домашньому насильству : Закон України від 07.01.2017 р. № 2229-VIII. URL: https://zakon.rada.gov.ua/laws/show/2229-19 (дата звернення: 03.09.2019).

8. Про затвердження Порядку винесення уповноваженими підрозділами органів Національної поліції України термінового заборонного припису стосовно кривдника : Наказ Міністерства внутрішніх справ України від 01.08.2018 р. № 654. URL: https://zakon.rada.gov.ua/laws/show/z0965-18 (дата звернення: 05.10.2019).

9. Про національну поліцію України : Закон України від 2.07. 2015 p. № 580-VIII. URL: https://zakon.rada.gov.ua/laws/show/2229-19 (дата звернення: 06.10.2019).

10. Щороку в Україні від домашнього насильства гинуть 600 жінок. Unian.ua. 9.11.2017. URL: https://www.unian.ua/society/2233774-schoroku-vukrajini-vid-domashnogo-nasilstva-ginut-600-jinokinfografika.htmlhttps://www.unian.ua/society/ 2233774 -schoroku-v-ukrajini-vid-domashnogonasilstva-ginut-600-jinok-infografika.html (дата звернення: 01.09.2019).

\section{Анотація}

Кузьменко Ю. В. Адміністративна діяльність Національної поліції: протидія та запобігання домашньому насильству. - Стаття.

У статті висвітлено адміністративний аспект діяльності Національної поліції щодо реалізації Закону України «Про запобігання та протидію домашньому насильству», розкрито шляхи вирішення зазначеної проблеми працівниками поліції. Зокрема, наведено перелік розділів та статей Закону України «Про запобігання та протидію домашньому насильству", де окреслено механізми та вимоги до поліції щодо втілення даного закону в дію. Сучасне реформування нормативно-правового простору свідчить про розвиток демократичних цінностей в нашому суспільстві, про здатність захисту своїх громадян від сексуального, фізичного, психологічного та економічного насильства в сім'ї. Автором також підкреслено важливість ролі органів Національної поліції щодо вирішення цієї проблеми в аспекті суспільного резонансу домашнього насильства. Адміністративна діяльність Національної поліції сьогодні суттєво розширена спеціальними заходами, що можуть застосовуватися відносно кривдника як у разі вчинення ним домашнього насильства, так і у разі висловлення погрози його здійснення. Усі ці заходи покликані захищати постраждалих осіб від домашнього насильства та попереджувати його. Наведено основний перелік законів, постанов, які регламентують дії працівника поліції у таких випадках. Особливу увагу акцентовано на Порядку проведення оцінки ризиків вчинення домашнього насильства та Порядку винесення уповноваженими підрозділами органів Національної поліції України термінового заборонного припису стосовно кривдника. Зазначається, що бланк заборонного термінового припису має спеціальну встановлену форму та серію (дві літери) і номер (шестизначний цифровий показник), а у разі його зіпсування він вважається недійсним і підлягає знищенню в установленому порядку. Також подано перелік обов'язкових дій патрульних та дільничних офіцерів поліції при виявленні фактів домашнього насильства та у випадках, коли воно не було виявлено. 
Ключові слова: домашнє насильство, запобігання і протидія, Національна поліція, законодавство України, обов'язки поліцейського.

\section{Summary}

Kuzmenko Yu. V. Administrative activities of the National Police: countering and preventing of the domestic violence. - Article.

The article highlights the administrative aspect of the activities of the National Police in implementing the Law of Ukraine "On Preventing and Countering Domestic Violence", there are disclosed the ways to solve this problem by police officers. In particular, there were given a list of sections and articles of the Law of Ukraine "On the Prevention and Counteraction of Domestic Violence", where were identified the mechanisms and requirements for the police to translate this law into force. Modern reform of the legal space speaks of the development of democratic values in our society, of the ability to protect our citizens from sexual, physical, psychological and economic violence in the family. The author also emphasized the importance of the role of the National Police in solving this problem in terms of public dissonance of the prob- lem of domestic violence. The administrative activities of the National Police today are significantly expanded by special measures that can be applied to the offender both in the event of domestic violence or the threat of its implementation. All these measures are designed to protect and prevent victims of domestic violence. There is provided the main list of laws and regulations governing the actions of a police officer in such cases. Particular attention is focused on the Procedure for assessing the risks of committing domestic violence and the Procedure for the issuance by the authorized units of the national police of Ukraine of an urgent prohibition on the offender. It is noted that the form of the forbidden urgent order has a special established form and has a series (two letters) and a number (six-digit digital indicator), and if it is damaged, it is considered invalid and must be destroyed in the prescribed manner. Also there is presented a list of mandatory actions by patrol and district police officers when identifying facts of domestic violence, and in cases where it is not detected.

Key words: domestic violence, prevention and counteraction, National Police, Ukrainian legislation, police duties. 